Purdue University

Purdue e-Pubs

Purdue CIBER Working Papers

Krannert Graduate School of Management

$1-1-2003$

Trade and the (Dis) Incentive to Reform Labor Markets: The Case of Reform in the European Union

George Alessandria

University of Pennsylvania

Alain Delacroix

Purdue University

Follow this and additional works at: http:// docs.lib.purdue.edu/ciberwp

Alessandria, George and Delacroix, Alain, "Trade and the (Dis) Incentive to Reform Labor Markets: The Case of Reform in the European Union" (2003). Purdue CIBER Working Papers. Paper 27.

http://docs.lib.purdue.edu/ciberwp/27

This document has been made available through Purdue e-Pubs, a service of the Purdue University Libraries. Please contact epubs@purdue.edu for additional information. 


\title{
Trade and the (Dis) Incentive to Reform Labor Markets: The Case of Reform in the European Union*
}

\author{
George Alessandria \\ University of Pennsylvania \\ Ohio State University
}

November 10, 2003

\author{
Alain Delacroix \\ Purdue University
}

\begin{abstract}
In a closed economy general equilibrium model, Hopenhayn and Rogerson (1993) find large welfare gains to removing firing restrictions. We explore the extent to which international trade alters this result. When economies trade, labor market policies in one country spill over to other countries through a change in the terms of trade. This reduces the incentive to reform labor markets. In a policy game over firing taxes between countries, we find that countries optimally choose positive levels of firing taxes. A coordinated elimination of firing taxes yields considerable benefits. This insight provides some explanation for recent efforts toward labor market reform in the European Union.
\end{abstract}

\footnotetext{
${ }^{*}$ Corresponding author: Alain Delacroix, Purdue University, Krannert School of Management, 403 W. State Street, West Lafayette, IN 47907-2056, delacroixa@mgmt.purdue.edu. We wish to thank David Hummels, Dale Mortensen, Chris Pissarides, Richard Rogerson, Robert Shimer, Marcelo Veracierto, Gianluca Violante and Randy Wright as well as participants at the 2003 NBER Summer Institute and 2003 Conference for the Advancement of Economic Theory for their comments and suggestions.
} 
In a world where business must respond quickly and people must adapt to change, Europe has too often been unwilling to go beyond old assumptions that the labour, capital and product market flexibility necessary for productivity is the enemy of social justice.

[Gordon Brown, Chancellor of the Exchequer, U.K. Treasury]

\section{Introduction}

Continental European labor markets are characterized by a number of regulations which limit the willingness of firms to create and destroy jobs. These policies appear to contribute to the generally higher levels of unemployment in Europe relative to the U.S. Among these regulations, Hopenhayn and Rogerson (1993) and Veracierto (2001) find that firing restrictions also generate significant welfare costs. Despite these costs individual European economies maintain these policies. Some recent discussions of reform have occurred within the multilateral framework of the European Union. In these discussion, the U.K., the country with the fewest regulations on job turnover, is the strongest proponent of reform of firing restrictions.

This article has three goals. First, we seek to understand the reluctance of individual European countries to eliminate unilaterally firing restrictions. Second, we would like to explain why labor market reform is being initiated through multilateral channels. And third, we would like to understand why the U.K. is pushing for labor market reform by its trading partners. For this purpose, we develop a two country, general equilibrium model of establishment dynamics and international trade. The model is calibrated to European data and the effect of firing taxes are analyzed.

This article is closely related to the analysis of firing taxes by Hopenhayn and Rogerson (1993) and Veracierto (2001). ${ }^{1}$ It extends their analysis by introducing international trade and permits us to analyze the international transmission of domestic firing restrictions. ${ }^{2}$ Given that European economies are tightly

\footnotetext{
${ }^{1}$ Bentolila and Bertola (1990) and Millard and Mortensen (1997) find that firing taxes reduce both job creation and job destruction and thus have an ambiguous effect on employment. Delacroix (2003) and Ljungqvist (2002) determine how the net effect on employment depends on the nature and timing of firing costs.

${ }^{2}$ Fogli (2000) and Saint-Paul (2002a) have attributed the emergence and persistence of these labor market policies to political economy considerations. Saint-Paul (2000) suggests that under certain conditions a two-tier reform system may be successful in implementing reform. We abstract from this channel to focus on the international transmission of these policies and the interaction between countries. These interactions imply that a multilateral approach is necessary for successful reform.
} 
integrated through trade, this provides a more accurate measure of the welfare costs of removing firing restrictions for European economies. It also allows us to consider the role of trade in determining firing tax policies. We consider the choice of domestic policy as the outcome of a policy game between countries.

The economy considered is a two country, two good model of Ricardian trade. Each country specializes in the production of a single good. Within each country, this good is produced by a large number of heterogenous firms facing persistent idiosyncratic technology shocks. Firms respond to these shocks by entering and exiting, expanding and contracting over time. Firing taxes distort the firms employment decision as firms are less prone to hire and fire workers. Thus, firing taxes create both a productive inefficiency and competitive inefficiency. The productive inefficiency occurs as the firing costs imply that the marginal product of labor is not equal across firms. The competitive inefficiency occurs because all firms are dying in expected terms so that firing taxes are a tax on the lifecycle of a firm. This competitive effect lowers the real wage. Combined, these two effects lead workers to substitute leisure for market activity leading to a reduction in aggregate employment and output. Previous work quantifies the magnitude of these effects and determines the implication for welfare. In our model, the reduction in output improves the terms of trade of the country with the firing costs and provides a possible benefit to domestic agents. ${ }^{3}$ It implies that some of the welfare costs of this policy are shared by foreign agents.

Similar to Hopenhayn and Rogerson (1993) and Veracierto (2001), we find that firing taxes equal to eleven months of wages reduce steady state output by 3.43 percent, consumption by 3.17 percent and employment by 4.50 percent in the country with the firing taxes. In contrast to previous work, we find these taxes have a sizable effect on a country's trading partners, reducing foreign consumption by 0.97 percent through a 4.13 percent worsening of its terms of trade. Because of this trade linkage, we find that unilaterally eliminating firing taxes lowers welfare by 0.09 percent of steady state consumption in the country undertaking reform and raises the trading partner's welfare by 0.97 percent of steady state consumption. This large spillover occurs even with moderate amounts of international trade of twenty percent of GDP. Consequently, by welfare measures, countries have no incentive to eliminate these firing costs. Moreover, countries without firing taxes, like the UK, have the most to gain from reform by their trading partners.

To explore the determination of firing costs, we consider a non-cooperative policy game between countries

\footnotetext{
${ }^{3}$ All of the benefits in this model are due to the change in the terms of trade. Alvarez and Veracierto (2001) consider the potential benefits of firing restrictions when there are financial and relocation frictions.
} 
over firing taxes. ${ }^{4}$ We find that countries optimally choose a level of firing taxes in equilibrium which are consistent with those currently in place in France, Germany and Italy. A coordinated elimination of firing taxes by European economies provides a welfare gain of approximately 0.88 percent of lifetime consumption. In contrast, Mendoza and Tesar (2002) find the welfare gains to international coordination of more conventional capital and labor taxes are approximately 0.12 percent of lifetime consumption.

Many researchers have investigated the economic effects of domestic labor market distortions and international trade. ${ }^{5}$ Most work in this area focuses on minimum wage policies and the pattern of comparative advantage and employment. ${ }^{6}$ Closely related to our work is Saint-Paul (2002b), who studies the role of firing costs for the pattern of trade. In a model with a product life cycle, Saint-Paul finds that firing taxes shift countries towards industries with stable demand - mature goods late in product life-cycle. Firing taxes may improve welfare when specializing in the secondary innovation to produce mature goods yields efficiency gains. Calmfors (2001) and Sibert and Sutherland (2001) study the incentive to reform labor markets in a monetary union. These papers focus on the use of monetary policy to reduce structural unemployment and respond to asymmetric shocks through a temporary change in the terms of trade.

The paper is organized as follows. Section 2 summarizes some recent developments in Europe to reform labor markets. Section 3 describes the baseline model. In section 4, we discuss the competitive equilibrium and in section 5, the model is calibrated to a composite of the three largest European economies for which firing costs are considered to be high - France, Germany, and Italy. In section 6, the quantitative effects of a change in policy are analyzed. Section 7 explores the sensitivity of the results to parameter values, the nature of firing costs and the ability to relocate production internationally. The results do not change qualitatively. In section 8, we consider a non cooperative game over labor market policies between countries. Section 9 concludes and considers possible extensions.

\footnotetext{
${ }^{4}$ Persson and Tabellini (1995) provide a summary of the literature on international policy competition which focuses primarily on monetary, fiscal or trade policy.

${ }^{5}$ Bhagwati (1971) provides a concise summary of the theory of international trade under domestic distortions.

${ }^{6}$ Brecher (1974) finds that minimum wage policies may reverse the pattern of comparative advantage. Davis (1998a,b) shows that minimum wage policies when there is international trade generate considerably more unemployment than in a closed economy.
} 


\section{The European context}

Beginning with the 1997 Luxembourg Extraordinary European Council Meeting on Employment and continuing in subsequent Council meetings, the member states of the European Union have met to discuss the unemployment situation in Europe. ${ }^{7}$ The result is the European Employment Strategy (EES) which seeks to improve employability, develop entrepreneurship, encourage adaptability in businesses and their employes and strengthen the policies for equal opportunities. ${ }^{8}$ The EES emphasizes the use of funded active labor market policies such as training, employment subsidies and job search assistance, with little reference to employment protection legislation (EPL). The EES is carried out through an "open method of coordination" between Member States. The European Council in Lisbon in 2000 built upon the foundations of the Luxembourg Summit and set a new strategic goal for the next decade, defined as the Lisbon Strategy, to "become the most competitive and dynamic knowledge-based economy in the world, capable of sustainable economic growth with more and better jobs and greater social cohesion," with policies aiming at "modernizing the European social model by investing in people and building an active welfare state." It also refined the coordination method by agreeing that, every year, the European council should agree on employment guidelines for each Member State.

The EES provided for an impact evaluation five years after the Luxembourg summit. ${ }^{9}$ Not surprisingly, given the initial focus of the EES, almost all changes reported involve active labor market policies. In fact, the few modifications to the employment protection legislation in various European countries since 1998 have shown no clear trend, some reforms or proposals corresponding to liberalization of EPL, others to its tightening (Young 2003). ${ }^{10}$ It is to be noticed, however, that starting in 2001, the Council recommendations for the individual countries did mention the need to adapt employment regulations "to ensure a balance between flexibility and security for the labour force."

The Lisbon Strategy can be contrasted with the U.K.'s approach towards labour market reform. For that,

\footnotetext{
${ }^{7}$ The European Council brings together the Heads of State or Government of the fifteen Member States of the European Union and the President of the European Commission. The decisions taken at the European Council meetings are a major impetus in defining the general political guidelines of the European Union.

${ }^{8}$ See the Presidency Conclusions to the various Council Meetings.

${ }^{9}$ Impact Evaluation of the European Employment Strategy - Technical Analysis, supporting COM(2002) 416 final of 17.7.2002.

${ }^{10}$ Although EPL tightened across Europe in the 1960's and 1970's, changes since the 1980's have also shown no clear trend. The introduction of fixed-term contracts has been the only significant change (in some countries), but its use has also been regulated in some countries (Bertola, Boeri and Cazes 1999).
} 
one can look at speeches made by the Chancellor of the Exchequer at the U.K. Treasury. Going back to 1997 - and prior to the Luxembourg summit, a special summit of the G8 was organized in the U.K. Chancellor Brown commented that "employability is the key to a cohesive society which offers opportunity to all its citizens. [...] This is a new economic agenda. It enables us to benefit from flexible labour markets [...]. We intend to make this a key to both our Presidency of the G8 and the European Union." ${ }^{11}$ Following the G8 summit, Chancellor Brown commented on the London Principles resulting from the conference, which include "the need for structural reforms in our labor markets." ${ }^{2}$ Finally, in February 2002, the UK treasury and Department of Trade and Industry jointly published a White paper "Realizing Europe's Potential," emphasizing the challenging reforms ahead, in particular "a commitment to better regulation across Europe $[\ldots]$, slashing red tape [...] and to more intelligent regulation stimulating enterprises amongst our business community." 13

In fairness, there is harmony between the Lisbon Strategy and the London Principles on active labor market policies. However, the London Principles also emphasize reform aimed at labour market flexibility. Our model allows us to address two related questions. First, why is the U.K., which has already reformed its EPL, pushing for such reforms in the rest of Europe? Second, which is the better way to achieve reform for the European countries, unilateral reform or concerted action at the pan-European level?

\section{Model}

The following framework generalizes the environment developed by Hopenhayn and Rogerson (1993) to an international context. There are two dominant approaches to modelling international trade. First, there are models in which trade is based on differences between countries. These are commonly referred to as models of national product differentiation and include models where countries differ by technology, preferences or endowment. The second approach is built on increasing returns to scale. While both models provide plausible explanations for trade, the evidence favors the national product differentiation and leads us to adopt this

\footnotetext{
11 "Employability to top the agenda in the U.K. G8 conference," UK Treasury press release, May 29, 1997. Another press release prior to the Luxembourg summit, dated July 18, 1997, is entitled "Chancellor takes job crusade to Europe."

12 "G8 employability action plans published," UK Treasury press release, May 9, 1998.

13 "White Paper sets out vision for European economic reform," UK Treasury press release, February 28, 2002. Another press release, "Meeting the challenge of economic reform in Europe," February 17, 2003, basically delivers the same message.
} 
approach. $^{14}$

Assume there are two countries, $i=1,2$, each producing an imperfectly substitutable good, denoted by $\mathcal{X}$ and $\mathcal{Y}$. Country 1 specializes in the production of good $\mathcal{X}$ and country 2 specializes in good $\mathcal{Y}$. At time $t$, the price of a unit of good $\mathcal{X}$ is $p_{t}$ and the price of a unit of good $\mathcal{Y}$ is $q_{t}$.

In each country a large number of firms produce the domestic good. Each firm uses labor as its only input and begins the period with a stock of workers from the previous period, $n_{t-1}$. At the beginning of the period, firms are subjected to an idiosyncratic productivity shock, $s_{t}$, and respond by adjusting their employment levels. A firm in country 1 facing a price of $p_{t}$ for its output makes period profits of

$$
p_{t} f\left(s_{t}, n_{t}\right)-w_{i t} n_{t}-g_{i}\left(n_{t}, n_{t-1}\right),
$$

where $g_{i}\left(n_{t}, n_{t-1}\right)$ is a cost the firm incurs to adjust its employment level from $n_{t-1}$ to $n_{t}$. This adjustment cost may differ across countries due to different labor market policies. We focus on the role of firing costs and assume that firms must make a fixed payment of $\tau_{i} w_{i}$ for each job they destroy so that

$$
g_{i}\left(n_{t}, n_{t-1}\right)= \begin{cases}\tau_{i} \cdot w_{i} \cdot \max \left\{0, n_{t-1}-n_{t}\right\} & \text { if } n_{t-1} \geq \text { threshold } \\ 0 & \text { otherwise }\end{cases}
$$

where $w_{i}$ is the wage prevailing in the current period. This structure for firing costs reflects the practice in European economies to exempt small firms from such regulations.

The firm specific shocks are independent across firms, but the stochastic process for shocks is common to all firms. The shock $s_{t}$ follows a first order Markov process and takes values in the set $S=\{0\} \cup[1, \infty)$. The transition function $Q\left(s, s^{\prime}\right)$ defines the probability $s_{t+1}=s^{\prime} \in S$ given $s_{t}=s$. Firms that receive the zero productivity shock will never receive a positive productivity shock again $(Q(0,0)=1)$ and are viewed as exiting the market. ${ }^{15}$ To exit the market a firm must fire all of its current workers and pay any dismissal costs. As an exiting firms has no revenue, its dismissal payment are covered by the owners of the firm.

Next, consider the decision of potential entrants. There is a large number of ex-ante identical potential entrants in each period. Entrants must incur a one time, up-front cost of $c_{e}$ denominated in units of the

\footnotetext{
${ }^{14}$ Head and Ries (2001) test these models using a panel of Canadian and US manufacturing industries. Harrigan (1997 and 1999) find evidence of differences in the TFP across countries in identical sectors, supporting the NPD approach. Trefler (1995) finds that international differences in technology and tastes are crucial to predicting the pattern of trade.

${ }^{15}$ An alternate approach would be to allow shocks to be on $\mathbb{R}_{+}$but require firms to pay a fixed cost of producing each period as in Hopenhayn and Rogerson (1993).
} 
locally produced good. Entrants incur this cost at the end of period $t$ and then can enter the market in period $t+1$. In period $t+1$, each entrant draws an idiosyncratic shock from the distribution $\nu(s)$ and then hires workers and begins production. An entrant in period $t$ becomes an incumbent with no stock of employees in period $t+1$. The distribution of $\nu$ is the same each period and does not depend on the number of new entrants or existing firms.

The preferences of agents in each country are characterized by the expected utility function

$$
u_{i}=E_{0} \sum_{t=0}^{\infty} \beta^{t}\left[u\left(c_{i t}\right)-v\left(n_{i t}\right)\right],
$$

where $c_{i t}$ and $n_{i t}$ are consumption and hours worked in country $i$. Consumption is a composite of the foreign and domestic goods with

$$
\begin{aligned}
c_{1 t} & =c\left(x_{1 t}, y_{1 t}\right), \\
c_{2 t} & =c\left(y_{2 t}, x_{2 t}\right) .
\end{aligned}
$$

We follow Hansen (1985) and Rogerson (1988) and assume that labor is indivisible and allow agents to trade lotteries on the probability of working. Indivisibility of labor is now a common assumption in computable models. In this context, this assumption is necessary for the number of employees at a firm to be well defined. The economy behaves as if there was a representative agent with preferences defined by

$$
V_{i}=\sum_{t=0}^{\infty} \beta^{t}\left[u\left(c_{i t}\right)-A N_{i t}\right],
$$

where $N_{i t}$ is the fraction of agents in country $i$ employed at time $t$. Every period, households purchase consumption using income received from supplying labor, profits of $\Pi_{i t}$ from owning firms, and lump sum transfers of $R_{i t}$ from the government. These transfers are rebates to consumers of the firing costs collected from the firms. Firms are owned exclusively by domestic consumers and there is no intertemporal asset trade. The period budget constraint of a country $i$ consumer in period $t$ is

$$
p_{t} x_{i t}+q_{t} y_{i t}=w_{i t} N_{i t}+\Pi_{i t}+R_{i t} .
$$

We abstract from international asset trade for two reasons. First, empirically there is substantial evidence of home bias in asset ownership (Lewis 1999) and very little evidence of risk sharing across countries (Backus and Smith 1993). Our second reason is more practical. With international asset trade, a country will share 
the welfare gains to its domestic labor market policies by definition. With no trade in assets, the budget constraints imply the following trade balance equation

$$
p_{t} x_{2 t}=q_{t} y_{1 t}
$$

\section{Competitive Equilibrium}

This section describes a stationary competitive equilibrium. With firing taxes, the firm's problem is dynamic as firms maximize the expected value of discounted profits net of firing costs. The individual state of a firm is its stock of workers from the last period, $e$, and its current productivity level, $s$. The problem of firms in country 1 is described by the following Bellman's equation

$$
V_{1}(s, e)=\max _{n \geq 0}\left\{p f(s, n)-w_{1} n-g_{1}(n, e)+\frac{1}{1+\rho} \int V_{1}\left(s^{\prime}, n\right) Q\left(s, d s^{\prime}\right)\right\} .
$$

A similar problem exists for firms from country 2. This problem leads to a well defined policy rule, $N_{1}(s, e)$ which can be used to determine period profits $(\pi)$ and firing cost payments $(r)$ :

$$
\begin{aligned}
& \pi_{1}(s, e)=p f\left(s, N_{1}(s, e)\right)-w_{1} N_{1}(s, e)-g_{1}\left(N_{1}(s, e), e\right), \\
& r_{1}(s, e)=g_{1}\left(N_{1}(s, e), e\right) .
\end{aligned}
$$

For new entrants, the value of entering is equal to the discounted expected value of beginning tomorrow with technology $s$ and no workers, where the shock $s$ is drawn from the distribution $\nu$. The free entry condition then implies that

$$
\begin{aligned}
& p c_{e}=\frac{1}{1+\rho} \int V_{1}(s, 0) d \nu(s) \\
& q c_{e}=\frac{1}{1+\rho} \int V_{2}(s, 0) d \nu(s)
\end{aligned}
$$

in country 1 and 2 respectively.

The state of the economy is characterized by the distribution of individual firm state variables in each country. Let $\mu_{i}$ denote the measure over employment and productivity levels $(e, s)$ of incumbent firms in country $i$. In period $t$, this measure does not include the entrants that incurred the fixed cost in period $t-1$, but have yet to produce. These entrants are included as incumbents in the $t+1$ distribution $\mu_{i}^{\prime}$. Let $M_{i}$ 
represent the mass of entrants. The transition from $\mu_{i}$ to $\mu_{i}^{\prime}$ is denoted by $\mu_{i}^{\prime}=T\left(\mu_{i}, M_{i}\right)$. In a stationary economy, $\mu_{i}=T\left(\mu_{i}, M_{i}\right)$.

Having defined the measure of incumbents and entrants, some aggregates can be computed. Let $X\left(\mu_{1}, M_{1}\right)$ represent output in country 1 . Let $\Pi_{1}\left(\mu_{1}, M_{1}\right)$ represent aggregate profits of country 1 firms. Let $R_{1}\left(\mu_{1}, M_{1}\right)$ represent aggregate adjustment costs and let $N_{1}^{d}\left(\mu_{1}, M_{1}\right)$ denote the aggregate demand for labor by country 1 firms. Similar variables can be defined in country 2.

$$
\begin{aligned}
X\left(\mu_{1}, M_{1}\right) & =\int f\left[N_{1}(s, e), s\right] d \mu_{1}(s, e)+M_{1} \int f\left[N_{1}(s, 0), s\right] d \nu(s), \\
\Pi_{1}\left(\mu_{1}, M_{1}\right) & =\int \pi_{1}(s, e) d \mu_{1}(s, e)+M_{1} \int \pi_{1}(s, 0) d \nu(s)-M_{1} p c_{e}, \\
R_{1}\left(\mu_{1}, M_{1}\right) & =\int r_{1}(s, e) d \mu_{1}(s, e), \\
N_{1}^{d}\left(\mu_{1}, M_{1}\right) & =\int N_{1}(s, e) d \mu_{1}(s, e)+M_{1} \int N_{1}(s, 0) d \nu(s) .
\end{aligned}
$$

In a stationary equilibrium, the consumer's problem reduces to the following static optimization problem,

$$
\begin{gathered}
U_{i}=\max _{x_{i}, y_{i}, N_{i}} u_{i}\left(x_{i}, y_{i}\right)-A N_{i}, \\
\text { s.t. } p x_{i}+q y_{i}=w_{i} N_{i}+\Pi_{i}+R_{i} .
\end{gathered}
$$

The solution to this problem is characterized by the following first order conditions

$$
\begin{aligned}
& \frac{\partial u_{i}}{\partial x_{i}}=A \frac{p}{w_{i}}, \\
& \frac{\partial u_{i}}{\partial y_{i}}=A \frac{q}{w_{i}} .
\end{aligned}
$$

The labor supply can be solved from the budget constraint as

$$
N_{i}^{s}=\frac{p x_{i}+q y_{i}-\Pi_{i}-R_{i}}{w_{i}}
$$

Finally, the market clearing conditions are

$$
\begin{aligned}
& x_{1}+x_{2}+M_{1} c_{e}=X, \\
& y_{1}+y_{2}+M_{2} c_{e}=Y .
\end{aligned}
$$




\section{Calibration}

The parameter values are chosen so that the steady state in the model matches certain features of a composite of the German, French and Italian economies. These countries are our baseline as their firing costs are similar and large (Bentolila and Bertola 1990) and they are fairly well integrated economically. Following these authors, firing restrictions are set as 90 percent of annual wages. ${ }^{16}$ To reflect actual European regulations, we assume that firms with less than 15 employees are exempt from paying firing costs. Throughout the calibration, values for the composite European country are obtained using weights for the three countries, that reflect their employment shares. ${ }^{17}$

Parameters linked to aggregate data are straightforward to choose. The discount factor is set to 0.964 , which corresponds to a 4 percent annual interest rate. The production function parameter $\theta$ is set to 0.64 to match labor's share of income. The entry cost is chosen so that the price level is normalized to equal the domestic wage. ${ }^{18}$

The utility function and consumption aggregator have the following functional forms,

$$
\begin{aligned}
u(c) & =\ln c(x, y), \\
c(x, y) & =\left[\omega x^{\frac{\gamma-1}{\gamma}}+(1-\omega) y^{\frac{\gamma-1}{\gamma}}\right]^{\frac{\gamma}{\gamma-1}} .
\end{aligned}
$$

This form of consumption aggregation is common in the international trade literature (Armington 1969). The impact of domestic labor market policies are determined in part by international trade linkages. Given the consumption aggregator, these linkages depend entirely on the elasticity of substitution $\gamma$ and the home bias parameter $\omega>1 / 2$ (countries put a higher weight on their domestically produced good). Estimates of $\gamma$ vary widely in the literature depending on whether time series or cross sectional techniques are used. Time series ${ }^{19}$ studies estimate the Armington elasticity by regressing changes in trade flows on changes in relative prices and find that these elasticities are low, in the range of 0.5 to 1.5. These values are consistent with those

\footnotetext{
${ }^{16}$ They calculate firing costs to be (as a fraction of annual wages) 0.73 in Germany, 0.93 in France and 1.05 in Italy. Lazear (1990) finds severance payments of close to a year as well. In a study of the Italian economy, Garibaldi and Violante (2002) find firms incur considerably higher firing costs.

${ }^{17}$ The employment shares are from the IMF's International Financial Statistics database.

${ }^{18}$ This normalization is done since one cannot disentangle whether a high firm value is due to a high price or to a high expected value of idiosyncratic productivity.

${ }^{19}$ See Stern, Francis and Schumacher (1976), Shiells, Stern and Deardorff (1986), Shiells and Reinert (1993) and Galloway, McDaniel, Rivera (2003).
} 
used in the international business cycle research (Backus et al. 1992, Heathcote and Perri 2002, Corsetti, Dedola and Leduc 2003). Cross sectional studies ${ }^{20}$ estimate the Armington elasticity by regressing imports on a distance related measure of trade costs and find estimates in the range of 1 to 13 . We focus on the case with unitary elasticity of substitution between the two varieties as our benchmark.

To determine the trade integration, we compute the trade share of GDP as

$$
\text { Trade Share }=\frac{\text { EXPORTS+IMPORTS }}{2^{*} \mathrm{GDP}}
$$

where exports and imports measure trade in goods and services. These European countries are fairly open, with trade shares of about 30 percent compared to the US, which trades only about 12 percent of GDP. These trade shares have grown substantially in the past forty years for both the US and Europe (see figure 1). A substantial share of trade growth in Europe has come as a result of increased intra-European integration. Similarly, a substantial share of the growth in trade in the US has come from increased integration with Canada and Mexico, so that Europe and the US have become relatively less important trading partners (see table 3). The home bias parameter is chosen to generate a trade share of twenty percent, which matches the average trade share in Europe over the past forty years.

The idiosyncratic productivity shocks, the transition matrix $Q$ and the initial distribution of shocks (and the disutility of labor) are chosen to reproduce certain features of labor market data. In particular, we focus on matching three types of statistics: (i) employment ones, such as the proportion the labor force employed, (ii) firm distributional characteristics, such as average firm size, the distribution of firm size, and the contribution to employment by firm size, ${ }^{21}$ and finally (iii) statistics characterizing establishment dynamics, such as job creation (destruction) rate and exit rate by class size. We focus on the manufacturing sector as these goods are most often traded.

Table 2 summarizes the characteristics of employment and firm demographics that we seek to match. These statistics are calculated from an OECD dataset (see Bartelsman, Scarpetta and Schivardi 2003) collected to allow for international comparisons of firm demographics. Despite the difficulty in making international

\footnotetext{
${ }^{20}$ Hummels (2001) finds aggregate estimates of between 2 and 5, while Erkel-Rousse and Mirza (2002) estimate an aggregate elasticity between 1 and 13. Yi (2003) shows that in order to explain the growth in the level of trade from reductions in tariffs, that the elasticity of substitution should be closer to 10 .

${ }^{21} \mathrm{It}$ is important to match these two distributions, since even though very large firms are quite rare, they contribute a lot to total employment. As we will see later, changing the level of firing taxes affects the relative supply of goods in each country. We thus needed to make sure that all class sizes were given their actual contribution to output in the quantitative work.
} 
comparisons of this type, we are encouraged by the similarity of our three European countries. Relative to the US, European employment is concentrated in smaller firms. A final aspect of the data that we seek to match is the job creation rate between consecutive periods from Davis, Haltiwanger and Shuh (1998). For our synthetic European economy, job creation rates are 9.5 percent at the annual level.

We allow for ten positive technology shocks. Five of these shocks are chosen to match the mean employment level in each bin $\{5,30,70,200,1500\}$ from the data and five are chosen as the endpoints of the employment intervals $\{20,50,100,500,5000\}$. The size of the employment grid is 500 employment levels spaced between one and a maximum of 5,000 employees.

To determine the transition matrix, we make a few assumptions. ${ }^{22}$ First, we allow the failure rate to decline with the size of the technology shock. We choose the failure rate to drop from ten percent for the lowest technology to 1.5 percent for the best technology. Second, we constrain the probability of remaining in the same state to be the same for firms with technology $s_{i}$ and $i \in[1,9]$. We allow the persistence for the first and last shocks to be higher but constrain these to be the same. Finally, we assume that shocks only change a firms technology by one technology level per period, with the probability of becoming less productive exceeding that of becoming more productive.

Table 1 reports the parameters of the model. Table 2 demonstrates that the model economy matches up well with establishment dynamics in our European aggregate.

\section{Results}

In this section, we report how the steady state of the world economy changes when labor market frictions are removed. ${ }^{23}$ Since labor market regulations are more prevalent in Europe, in our baseline both countries impose firing costs. We consider two policies: either remove all firing costs (i.e. $\tau=0$, hence a flexible economy) or maintain the current level of taxes (i.e. $\tau=.9$, hence a rigid economy). The analysis proceeds in two steps. First, we examine the steady state when both countries have flexible labor markets (FF). This coordinated change in policies allows us to determine how firing taxes distort labor markets and the welfare gains to

\footnotetext{
${ }^{22}$ An alternative is to discretize a stochastic process for the shocks as in Veracierto (2001). We found that our approach lead to a better fit with the characteristics of the employment and firm distributions.

${ }^{23}$ We focus on steady states as Veracierto (2001) finds that transitional dynamics have a small quantitative impact on welfare calculations.
} 
removing these distortions. Next, we examine the world equilibrium when the domestic economy unilaterally lowers its firing taxes to zero (we call this the flexible-rigid case - FR). This unilateral move induces a terms of trade effect, which distorts the division of welfare gains across the two countries. To quantify the benefit of policy changes, we calculate the percentage decrease in steady state consumption a consumer would be willing to give up to adopt a particular policy. The focus here is primarily on welfare rather than the firm and employment demographics as these have been studied elsewhere. ${ }^{24}$ Table 4 summarizes the results of these experiments.

\subsection{Flexible-Flexible Case}

Firing restrictions substantially reduce employment, output, consumption and wages. If both countries eliminate these restrictions, then steady state output will increase by 3.43 percent, consumption by 4.13 percent, employment by 4.50 percent and real wages by 4.13 percent in each country. As both countries pursue the same policy there is no change in the terms of trade so that the model's results are identical to the closed economy case. By our welfare measure, agents in each country gain 0.88 percent of steady state consumption.

Firing restrictions distort the ability of firms to adjust to technology shocks. They also are a tax on the lifecycle of firms given that existing firms expect to shrink and eventually go out of business. Both of these effects, lower the real wage $(w / p)$ in each country so that workers substitute leisure for market work. Because of this substitution of leisure for consumption, the reduction in welfare is considerably smaller than the reduction in consumption.

For the United States, Hopenhayn and Rogerson (1993) and Veracierto (2001) find firing costs have larger costs in terms of quantities and welfare. Our findings differ as we consider firing taxes that exempt small firms. Since most firms are small, many firms do not pay firing costs. This permits small firms to adjust fully to some technology shocks. It also leads some small firms to delay expansion. With decreasing returns to scale, this tends to raise the productivity of small firms relative to large firms. Consequently, exempting small firms from firing taxes substantially reduces the productive inefficiency. As this is the main channel through which welfare is lowered in Hopenhayn and Rogerson (1993) and Veracierto (2001), we find smaller welfare costs. In practice, firing restrictions exempt small firms so that the previous estimates of their welfare costs are overstated. We now explore how trade linkages affect the division of welfare gains, rather than their

\footnotetext{
${ }^{24}$ For the impact of firing costs on firm dynamics see Hopenhayn and Rogerson (1993) or Veracierto (2001).
} 
magnitude.

\subsection{Flexible-Rigid Case}

Eliminating firing restrictions in just one country, leads to an increase in steady state output by 3.43 percent, consumption by 3.17 percent, employment by 4.50 percent and real wages by 4.13 in the flexible economy. The country that remains rigid experiences a 0.97 percent increase in consumption as its imports become 4.13 percent less expensive. There are no changes in employment, output, or real wages in the rigid economy given the utility structure ${ }^{25}$ and because entry costs only depend on the price of local inputs.

In total, welfare in the rigid economy increases by 0.97 percent, but the flexible economy actually experiences a welfare loss of -0.09 percent. This loss occurs because the large change in output worsens the terms of trade so that the gains in consumption do not offset the foregone leisure. This result is similar to the immiserizing growth result of Bhagwati (1958), where growth in output deteriorates the terms of trade so that real income is reduced. This is not the case here. The flexible country can afford more, but this extra consumption does not compensate workers for giving up leisure.

In our case, neither country has an incentive to eliminate its firing restrictions so that they are caught in a Prisoners' Dilemma. Regardless of the level of taxes in the other country, each country is better off imposing, or maintaining, firing taxes on its labor market. Of course, in equilibrium, this is suboptimal. This suggests an additional rationale for why countries have been slow to eliminate these firing restrictions. We explore this idea further in section 8 .

\section{Sensitivity analysis}

Here we examine the sensitivity of our findings by varying assumptions about four features of the model. As expected, reducing the trade share or increasing the elasticity of substitution between goods reduces the amount that domestic labor market policies affect trading partners. We also consider firing costs that are not rebated back to households and find little change in the international division of benefits of labor market reform. Finally, we allow production of both goods in each country with different production possibilities and also find little change.

\footnotetext{
${ }^{25}$ Specifically, additively separable utility (linear in leisure) and unitary intertemporal elasticity of substitution.
} 


\subsection{Sensitivity to the calibration}

In this section, the sensitivity of our results to trade integration are examined. Two points are noted. First, the gains to unilaterally eliminating firing taxes may be small or negative. Second, even countries that trade little tend to export a sizable portion of the benefit of these reforms. Together, these results suggest that increased international integration through trade may have weakened the incentive to unilaterally eliminate distortions in domestic labor markets.

We consider two possible levels for the trade share, five percent and twenty percent, and allow the elasticity of substitution to vary. Figure 2 plots the welfare gains from our two policy experiments - a coordinated elimination of firing taxes vs. a unilateral lifting of firing restrictions. ${ }^{26}$ If both countries move to flexible labor markets then welfare increases by 0.88 percent in each country regardless of the elasticity of substitution or trade share. Trade integration does not matter for the welfare effect because the coordinated reduction of policies scales up the supply of each good equally in steady state so that there are no changes in relative prices.

The gains to unilateral reform of the labor market increase with the substitutability of the goods. Varying the elasticity of substitution affects the relative importance of the income and substitution effects in the consumption aggregator. When $\gamma=1$, these effects cancel so that there are no wealth effects across countries (see Cole and Obstfeld 1993). When $\gamma<1$, the income effect dominates, leading to an even larger drop in the terms of trade for the flexible economy. Figure 3 plots the terms of trade effect by $\gamma$. We find there is a wide range of elasticities such that countries are made worse off from unilateral reform. With a trade share of twenty percent, a country benefits from reform only when $\gamma>1.1$. For $\gamma<1.75$, a country receives less than half of the benefit of reform.

With a low trade share of five percent, the country adopting a unilateral reform captures most of the benefits. However, even with unitary elasticity of substitution, the reformer captures only 72 percent of the benefit of the policy change. If goods are less substitutable, this drops further and the reforming country may be made worse off by reform.

\footnotetext{
${ }^{26}$ We are still considering that countries choose between two level of taxes only, $\tau=0$ and $\tau>0$.
} 


\subsection{Sensitivity to the nature of firing costs}

To check the robustness of our results with regards to the specific nature of firing costs, we tried an alternative assumption about firing taxes. Specifically, we assumed that firing costs were not transferred back to the workers. This can be justified on the ground that firing restrictions come in different forms. Although some costs may be considered as transfers between workers and firms - for example severance payments, ${ }^{27}$ others are pure taxes on the firm - for example, administrative and recordkeeping requirements. The model was recalibrated.

When firing costs are not transferred back to workers, the structure of the model is essentially the same. The budget constraint in the household's problem is modified to reflect that only profits are redistributed to workers and the market clearing conditions for goods $\mathcal{X}$ and $\mathcal{Y}$ are adjusted accordingly.

Table 4 reports the results pertinent to quantifying the spillovers of reform across countries. This is to be compared with the case where firing costs are rebated to workers. First, when $\gamma=1$, we still have spillovers of reform. The welfare gains from reform are higher and, in the case of unilateral reform, we find that approximately 29 percent of total welfare gains are now exported to the non-reforming country. Second, we find again that, as the two goods become less substitutable, economies may find themselves in a Prisoners' Dilemma, leading to a situation where in equilibrium, individual countries prefer to retain their firing restrictions (this happens when $\gamma$ falls below 0.6). In the present case however, removing firing restrictions implies that firms are going to operate closer to the efficient frontier and that household total income will not be negatively affected by the deadweight loss from the firing taxes. As a result, the terms of trade effect has to be stronger for a Prisoner Dilemma to arise (i.e. the goods have to be less substitutable).

\subsection{Sensitivity to relocation}

We now consider an economy in which both countries can produce both goods but with different technologies. In particular, we assume that upon paying the fixed entry cost firms make a once and for all decision to produce either good $\mathcal{X}$ or $\mathcal{Y}$. If a firm in country 1 chooses to produce good $\mathcal{X}$ then it faces the same stochastic shocks as before, but if it chooses to produce good $\mathcal{Y}$, it faces a different stochastic process denoted

\footnotetext{
${ }^{27}$ Or even advance notice of a layoff during which workers are still entitled to wage payments.
} 
$\widehat{Q}$ with a lower mean. The shocks $\widehat{s} \in \widehat{S}$ are scaled down by a factor $\phi$ so that

$$
\begin{aligned}
\widehat{s}_{i} & =\frac{s_{i}}{\phi} \quad s_{i} \in S, \\
\widehat{Q}\left(s^{\prime} \mid s\right) & =Q\left(\phi s^{\prime} \mid \phi s\right), \\
\widehat{v}(s) & =v(\phi s) .
\end{aligned}
$$

In country 2 , the situation is reversed so that firms producing good $\mathcal{Y}$ use the more productive technology and the firms producing good $\mathcal{X}$ use the less productive technology. In this case, trade is determined by comparative advantage so that the terms of trade will vary only if both countries specialize in the production of a single good.

For changes in firing taxes which have small effects on the terms of trade relative to the technology difference across countries, the results are the same as when specialization is exogenous. For changes in firing taxes which have large effects on the terms of trade, the models will differ as the terms of trade can vary only up to the point where one country begins to produce both goods.

The welfare gains to labor market reform and international trade depend on the technology difference across countries. Recent empirical work by Harrigan (1997 and 1999) finds large sectoral productivity differences across OECD countries. For instance, in 1988, relative to Germany, Harrigan (1997) finds that Italy is three percent less productive, France is one percent more productive, and the US is twenty percent more productive on average. In addition, productivity differences vary substantially across sectors. The standard deviation of sectoral productivity ranges from 5.3 percent between France and Germany to 14.1 percent between Italy and Germany. ${ }^{28}$

Figure 4 depicts the welfare gains of unilateral and coordinated reforms by technology difference $(\ln \phi)$ for the benchmark calibration. The welfare gain from a coordinated reform is identical to the previous case as both countries remain specialized. In the case of a unilateral reform, the welfare gain to agents in the flexible country is decreasing with the sectoral productivity difference. For small differences in technology, the reforming country captures nearly all of the benefits to reform as a small change in the terms of trade leads firms in the flexible country to enter their less productive sector. In this case, the terms of trade is determined

\footnotetext{
${ }^{28}$ Harrigan (1997) estimates total factor productivity in the Food, Apparel, Paper, Chemicals, Glass, Metals, and Machinery sectors. We compute the average productivity difference as an unweighted average of sectoral productivity differences. Industry measures of technology differences are more relevant than aggregate TFP as Harrigan finds that countries tend to produce and export relatively more goods from their more productive sectors.
} 
by the flexible country's production possibilities so that the flexible country does not gain from international trade. As the difference in technology increases, the rigid country captures more of the benefit of reform as it takes a larger change in the terms of trade before firms in the flexible country are willing to produce both goods. If there is a technology gap of about 1.9 percent, then the country that maintains the firing taxes gains more from reform than the newly flexible country. Once the technology gap reaches 3.8 percent, labor market reform lowers welfare in the flexible country.

\section{Policy competition}

Given a discrete choice of unilaterally eliminating firing taxes or maintaining them, we find that terms of trade considerations may lead countries to maintain their current policies. This suggests that a positive level of firing taxes may be an equilibrium outcome. We explore this possibility in a non-cooperative game between policymakers over the choice of firing taxes. For reasonable parameter values, we find that trade linkages alone may be enough to support the level of firing taxes currently in place. For our benchmark case, the equilibrium outcome of the policy game is five months of firing taxes.

Consider the following game. At time 0 , a policymaker in country $i$ chooses once and for all firing taxes $\tau_{i}$ for firms in country $i$. The policymaker is benevolent and chooses firing costs to maximize the steady state utility of its nationals. The policy maker does not consider the benefit to foreign nationals nor does it consider the benefits along the transition path to the steady state.

Consider the problem of the policy maker in country 1 . Given the policy in country $2, \tau_{2}$, the policy maker will choose firing taxes $\tau_{1}$ to maximize the steady state utility of domestic agents, $u_{1}\left(\tau_{1} ; \tau_{2}\right)$. More generally, the problem reduces to solving for firing taxes in country $i$ as a best response to firing taxes in country $-i$

$$
\tau_{i}^{B R}\left(\tau_{-i}\right)=\underset{\tau_{i}}{\arg \max } u_{i}\left(\tau_{i} ; \tau_{-i}\right) .
$$

A Nash Equilibrium is a fixed point to this policy game

$$
\left(\tau_{1}, \tau_{2}\right)=\left(\tau_{1}^{B R}\left(\tau_{2}\right), \tau_{2}^{B R}\left(\tau_{1}\right)\right)
$$

We let countries choose a level of taxes anywhere between 0 and 24 months of wages. ${ }^{29}$ Figure 5 plots the reaction curves of each country for $\gamma \in\{0.5,2\}$. The best response functions are flat as the choice of

\footnotetext{
${ }^{29}$ Restricted to an integer number of months.
} 
firing taxes is independent of the trading partner's level of firing taxes. This occurs because firing taxes in one country only affect consumption in the other country but not output nor hours. In particular, foreign firing taxes affect the absolute level of consumption in each country. Given this level of consumption, the percentage change in domestic consumption from domestic firing taxes primarily depends on the elasticity of substitution between goods. Consequently, the potential gains in increased leisure are solely determined by local firing taxes, while the division of the loss in consumption is determined by trade considerations.

Figure 6 plots the effect of firing taxes on employment and output in the base case. Output declines monotonically in firing taxes. The source of this decline varies with the level of firing taxes and is evident from examining the change in employment. For small firing taxes, employment declines substantially more than output so that the loss in consumption is small compared to the gain in leisure. For larger firing taxes, employment drops less and may actually increase. This implies that small firing taxes do not distort the efficiency of firms very much but are primarily a tax on firms. For larger firing taxes, the effect on productivity is larger.

Figure 7 reports the outcome of the policy game by the elasticity of substitution. In our baseline case of $\gamma=1$, with trade shares of twenty percent, the Nash Equilibrium is a world with five months of firing taxes. This is less but comparable to what we find in practice. Equilibrium firing taxes are decreasing in the elasticity of substitution (and increasing in trade). With a lower elasticity of substitution of approximately 0.65 , the equilibrium is eleven months of firing taxes.

In the baseline case, the welfare gains to a coordinated policy on firing taxes are 0.88 percent of lifetime consumption. These gains are significant compared to the gain of 0.12 percent of lifetime consumption that Mendoza and Tesar (2002) find from international coordination of labor and capital taxes in a two country, neoclassical growth model. The sizable difference in these findings suggest there are benefits to considering a broader range of policy tools in models with firm level heterogeneity.

\section{Conclusion}

This paper studies the impact of domestic labor market reform of firing restrictions on welfare in an international context. We find that international trade considerably weakens a country's incentive to undertake reform as much if not all of the gains are exported to its trading partners through a worsened terms of trade. 
In a model calibrated to match European data, we find that none of the gains to lifting firing taxes accrue to the country making the reforms. In fact, eliminating these firing costs actually lower welfare in the reformed country. These results arise because firing taxes substantially reduce output and employment and thus have strong terms of trade effects.

We find that the current level of firing taxes in Europe can be sustained as the Nash Equilibrium of a policy game between countries. This provides a possible rationale for the adoption of these firing costs. At the very least it provides a plausible explanation for their persistence. It also suggests there may be substantial benefits to international coordination to eliminate distortions in domestic labor markets. It is important that the European Council recognizes these benefits and continues to design the reform of continental labor markets at the multilateral level. These findings also suggest that the U.K. has the most to gain from reform in continental Europe, and may explain why the U.K. has been strongly pushing for these reforms.

These results are developed within a model of international trade driven by specialization. We have largely abstracted from the influence of firing costs on the pattern of trade or the export decision of firms. Much recent research has found that exporting firms have very different characteristics than non-exporters ${ }^{30}$ and that the identity of exporters changes over time. Firing restrictions are sure to influence this entry and exit. The current model can be easily extended to explore this avenue. Also, the model developed here is well suited to study the domestic and international implications of other policies that treat firms differently based on their employment such as small business loans or export promotion assistance programs.

Finally, the current paper is concerned with the influence of trade on labor market policies when there are no trade restrictions. Some recent work has explored the interaction between trade policy and labor market reforms. Kambourov (2003) studies the effectiveness of trade reform, when firing regulations interfere with the reallocation of labor across exporting and non-exporting sectors. Bagwell and Staiger (2001) study the incentives of WTO countries to manipulate tariffs and labor standards to improve their terms of trade and find negotiating and legal institutions under which an efficient outcome can be obtained. We can use our setup to investigate a related question: to what extent was the emergence of firing restrictions in European Union countries in the late 1960s and early 1970s a response to the consequence of increased trade integration. In other words, do countries which lose access to trade regulations as a policy instrument revert to other policies?

\footnotetext{
${ }^{30}$ See Bernard and Jensen (1999), Bernard, Eaton, Kortum and Jensen (2003).
} 


\section{References}

[1] Alvarez, Fernando and Veracierto, Marcelo. "Severance Payments in an Economy with Frictions." Journal of Monetary Economics, June 2001, 47(3) pp. 477-98.

[2] Armington, Paul S. "A Theory of Demand for Products Distinguished by Place of Production." International Monetary Fund Staff Papers, March 1969, 16(1), pp. 159-78.

[3] Backus, David; Kehoe, Patrick and Kydland, Finn. "International Business Cycles." Journal of Political Economy, August 1992, 100(4), pp. 745-75.

[4] Backus, David and Smith, Gregor. "Consumption and Real Exchange Rates in Dynamic Exchange Economies with Non-Traded Goods." Journal of International Economics, November 1993, 35(3-4) pp. 297-316.

[5] Bagwell, Kyle and Staiger, Robert. "Domestic Policies, National Sovereignty, and International Economic Institutions." Quarterly Journal of Economics, May 2001, 116 (2), pp. 519-62

[6] Bartelsman, E.; Scarpetta, S. and Schivardi, F. "Comparative analysis of firm demographics and survival: micro-level evidence for the OECD countries." OECD Economics Department Working Paper 348, January 2003.

[7] Bentolila, Samuel and Bertola, Giuseppe. "Firing Costs and Labor Demand: How Bad is Eurosclerosis?" Review of Economic Studies, July 1990, 57(3) pp. 381-402.

[8] Bernard, A. B.; Eaton, J., Jensen, J.B. and Kortum S. "Plants and Productivity in International Trade." American Economic Review, September 2003, 93 (4), pp. 1268-90.

[9] Bernard, Andrew B. and Jensen, Bradford. "Exceptional Exporter Performance: Cause, Effect, or Both?" Journal of International Economics, February 1999, 47(1), pp. 1-25.

[10] Bertola G.; Boeri T. and Cazes S. "Employment Protection and Labour Market Adjustment in OECD Countries: Evolving Institutions and Variable Enforcement." International Labour Office Employment and Training Papers, 1999. 
[11] Bhagwati, Jagdish. "Immiserizing Growth: A Geometrical Note," Review of Economic Studies, June 1958, 25, pp. 201-205.

[12] _ "The Generalized Theory of Distortions and Welfare." in J. Bhagwati, R.W. Jones, R.A. Mundell and J. Vanek, (eds.), Trade, balance of payments and growth: Papers in international economics in honor of Charles P. Kindleberger, Amsterdam: North Holland, pp. 69-90.

[13] Brecher, Richard. "Minimum Wage Rates and the Pure Theory of International Trade." Quarterly Journal of Economics, February 1974, 88 (1), pp. 98-116.

[14] Calmfors, Lars. "Unemployment, Labor Market Reform, and Monetary Union." Journal of Labor Economics, 2001, 19(2) pp. 265-289.

[15] Cole, Harold and Obstfeld, Maurice. "Commodity Trade and International Risk Sharing: How Much Do Financial Markets Matter?" Journal of Monetary Economics, August 1991, 28(1) pp. 3-24.

[16] Corsetti, Giancarlo; Dedola, Luca and Leduc, Sylvain. "International Risk-Sharing and the Transmission of Productivity Shocks." Working Paper, 2003.

[17] Davis, Donald. "Does European Unemployment Prop Up American Wages? National Labor Markets and Global Trade." American Economic Review, June 1998a, 88(3), pp. 478-94.

[18] _ "Technology, Unemployment and the Relative Wages in a Global Economy." European Economic Review, November 1998b, 42(9), pp. 1613-33.

[19] Davis, Steven; Haltiwanger, John and Shuh, Scott. Job Creation and Destruction. The MIT Press, 1998.

[20] Delacroix, Alain. "Transitions into unemployment and the Nature of Firing Costs." Review of Economic Dynamics, 2003, 6, pp. 651-71.

[21] Erkel-Rousse, H. and Mirza, D. "Import price elasticities: Reconsidering the evidence." Canadian Journal of Economics, 2002, 35, pp. 282-306.

[22] Fogli, Alessandra. "Endogenous Labor Market Rigidities and Family Ties.", Working Paper, 2000. 
[23] Gallaway, Michael P.; McDaniel, Christine A. and Rivera, Sandra A. "Short-Run and Long-Run IndustryLevel Estimates of U.S. Armington Elasticities." North American Journal of Economics and Finance, 2003, 14(1) pp. 49-68.

[24] Garibaldi, P. and Violante, G. "Severance Payment and Firing Tax in Search Economies: A Comparison", Working Paper, 2002.

[25] Hansen, Gary D. "Indivisible Labor and the Business Cycle." Journal of Monetary Economics, November 1985, 16(3), pp. 309-27.

[26] Harrigan, James. "Technology, Factor Supplies, and International Specialization: Estimating the Neoclassical Model." American Economic Review, September 1997, 87(4), pp 475-494.

[27] _ "Estimation of Cross-Country Differences in Industry Production Functions." Journal of International Economics, April 1999, 47 (2), pp. 267-93.

[28] Heathcoate, Jonathan and Perri, Fabrizio. "Financial Autarky and International Business Cycles" Journal of Monetary Economics, 2002, 49 (3), pp. 601-27.

[29] Head, Keith and Ries, John. "Increasing Returns versus National Product Differentiation as an Explanation for the Pattern of U.S.-Canada Trade." American Economic Review, September 2001, 91 (4) pp. $858-76$.

[30] Hopenhayn, Hugo and Rogerson, Richard. "Job Turnover and Policy Evaluations: A General Equilibrium Analysis." Journal of Political Economy, October 1993, 101(5), pp. 915-38.

[31] Hummels, David. "Towards a Geography of Trade Costs.", Working Paper, 2001.

[32] Kambourov, Gueorgui. "Labor Market Restrictions and the Sectoral Reallocation of Workers: The Case of Trade Liberalizations." Working Paper, 2003.

[33] Lazear, Edward. "Job Security Provisions and Employment." Quarterly Journal of Economics, 1990, 105 (3), pp. 699-726.

[34] Lewis, Karen. "Trying to Explain Home Bias in Equities and Consumption," Journal of Economic Literature, 1999 (37), pp. 571-608. 
[35] Ljungqvist, Lars. "How Do Layoff Costs Affect Employment?" Economic Journal, vol. 112, 2002, pp. $829-53$.

[36] Mendoza, Enrique and Tesar, Linda. "Tax Competition vs. Tax Coordination under Perfect Capital Mobility: The Supply Side Economics of International Tax Coordination," mimeo, University of Maryland, 2002.

[37] Millard, S. and Mortensen, D. "The unemployment and welfare effects of Labour Market Policy: A Comparison of the U.S. and U.K." in D. Snower and G. de la Dehesa (eds.), Unemployment Policy: How Should Governments Respond to Unemployment? Oxford University Press, 1997.

[38] Persson, T. and Tabellini, G. "Double-Edged Incentives: Institutions and Policy Coordination," Handbook of International Economics, vol. l III, edited by G. Grossman and K. Rogoff, 1995.

[39] Rogerson, Richard. "Indivisible Labor, Lotteries and Equilibrium." Journal of Monetary Economics, January 1988, 21(1), pp. 3-16.

[40] Saint-Paul, Gilles. The Political Economy of Labor Market Institutions. Oxford University Press, 2000.

[41] Saint-Paul, Gilles. "The Political Economy of Employment Protection." Journal of Political Economy, June 2002a, 110(3), pp. 672-704.

[42] Saint-Paul, Gilles. "Employment Protection, International Specialization, and Innovation." European Economic Review, 2002b (46), 375-95.

[43] Shiells, C. R. and Reinert, K. A. "Armington Models and Terms-of-Trade Effects: Some Econometric Evidence for North America." Canadian Journal of Economics, 1993, 26, pp. 299-316.

[44] Shiells, C. R.; Stern, R. M. and Deardorff, A. V. "Estimates of the Elasticities of Substitution Between Imports and Home Goods for the United States." Weltwirtschaftliches-Archiv, 1986, 122, pp. 497-519.

[45] Sibert, Anne and Sutherland, Alan. "Monetary Union and Labor Market Reform." Journal of International Economics, 2000, 51(2), pp. 421-35.

[46] Stern, R. M.; Francis, J. and Schumacher, B. Price Elasticities in International Trade: An Annotated Bibliography. London: Macmillan Press, 1976. 
[47] Trefler, Daniel. "The Case of Missing Trade." American Economic Review, December 1995, 85(5) pp. 1029-46.

[48] Veracierto, Marcelo. "Employment Flows, Capital Mobility, and Policy Analysis." International Economic Review, August 2001, 42(3), pp. 571-95.

[49] Yi, Kei-Mu. "Can Vertical Specialization Explain the Growth of World Trade?" Journal of Political Economy, February 2003, 111(1), pp. 52-102.

[50] Young, D. "Employment Protection Legislation: Its Economic Impact and the Case for Reform." European Commission Directorate-General for Economic and Financial Affairs, Economic Papers, 2003, No 186. 
Table 1 - Calibration

Preferences

$\beta=1 / 1.04 \quad A=2.142 \quad \gamma=1$

$$
\omega=.766
$$

Technology

$\theta=.64 \quad$ ce $=48.45$
Regulations

$\mathrm{T}=.9$

cutoff: 15 employees

Productivity Shocks

s0=0 s1=2.4 s2=4.1 s3=5.0 s4=5.6 $\quad$ s5=6.6 $\quad s 6=7.0 \quad s 7=8.0 \quad s 8=12.5 \quad s 9=15.0 \quad s 10=27.5$

Distribution Over Initial Productivity Shocks

$\mathrm{v} 0=.31 \quad \mathrm{v} 1=.51 \quad \mathrm{v} 2=.14 \quad \mathrm{v} 3=.03 \quad \mathrm{v} 4=0 \quad \mathrm{~s} 5=0 \quad \mathrm{v} 6=0 \quad \mathrm{v} 7=.0042 \mathrm{v} 8=.0018 \mathrm{~s} 9=0 \quad \mathrm{~s} 10=0$

Transition Probability (Q)

$\begin{array}{rrrrrrrrrrr}1 & 0.1 & 0.1 & 0.05 & 0.03 & 0.03 & 0.03 & 0.02 & 0.02 & 0.02 & 0.015 \\ 0 & 0.8 & 0.09 & 0 & 0 & 0 & 0 & 0 & 0 & 0 & 0 \\ 0 & 0.1 & 0.75 & 0.115 & 0 & 0 & 0 & 0 & 0 & 0 & 0 \\ 0 & 0 & 0.06 & 0.75 & 0.125 & 0 & 0 & 0 & 0 & 0 & 0 \\ 0 & 0 & 0 & 0.085 & 0.75 & 0.125 & 0 & 0 & 0 & 0 & 0 \\ 0 & 0 & 0 & 0 & 0.095 & 0.75 & 0.125 & 0 & 0 & 0 & 0 \\ 0 & 0 & 0 & 0 & 0 & 0.095 & 0.75 & 0.13 & 0 & 0 & 0 \\ 0 & 0 & 0 & 0 & 0 & 0 & 0.095 & 0.75 & 0.13 & 0 \\ 0 & 0 & 0 & 0 & 0 & 0 & 0 & 0.1 & 0.75 & 0.13 & 0 \\ 0 & 0 & 0 & 0 & 0 & 0 & 0 & 0 & 0.1 & 0.75 & 0.185 \\ 0 & 0 & 0 & 0 & 0 & 0 & 0 & 0 & 0 & 0.1 & 0.8\end{array}$




\section{Table 2 - Model and Data}

Model $\begin{gathered}\text { European } \\ \text { Aggregate }^{1}\end{gathered}$ Italy France* Germany US

\begin{tabular}{|c|c|c|c|c|c|c|}
\hline Avg Firm Size & 25.5 & 23.2 & 14.06 & 26.99 & 25.47 & 66.6 \\
\hline Job Creation & 0.094 & 0.095 & & & & \\
\hline Employment to Population Ratio & 0.66 & 0.66 & & & & \\
\hline \multicolumn{7}{|l|}{ Share Employment } \\
\hline$<20$ & 0.281 & 0.211 & 0.314 & 0.199 & 0.166 & 0.068 \\
\hline 20 to 50 & 0.128 & 0.135 & 0.159 & 0.162 & 0.107 & 0.069 \\
\hline 50 to 100 & 0.095 & 0.102 & 0.102 & 0.112 & 0.095 & 0.063 \\
\hline 100 to 500 & 0.201 & 0.248 & 0.194 & 0.241 & 0.280 & 0.147 \\
\hline $500+$ & 0.295 & 0.304 & 0.230 & 0.285 & 0.352 & 0.653 \\
\hline \multicolumn{7}{|l|}{ Share Firms } \\
\hline$<20$ & 0.838 & 0.831 & 0.887 & 0.779 & 0.835 & 0.729 \\
\hline 20 to 50 & 0.101 & 0.101 & 0.076 & 0.140 & 0.089 & 0.150 \\
\hline 50 to 100 & 0.037 & 0.034 & 0.021 & 0.043 & 0.035 & 0.061 \\
\hline 100 to 500 & 0.019 & 0.030 & 0.014 & 0.033 & 0.035 & 0.049 \\
\hline $500+$ & 0.005 & 0.005 & 0.002 & 0.005 & 0.006 & 0.012 \\
\hline \multicolumn{7}{|l|}{ Exit rate by bin } \\
\hline$<20$ & 0.095 & 0.101 & 0.093 & 0.127 & 0.090 & 0.094 \\
\hline 20 to 50 & 0.035 & 0.042 & 0.041 & 0.077 & 0.021 & 0.048 \\
\hline 50 to 100 & 0.028 & 0.031 & 0.032 & 0.063 & 0.011 & 0.040 \\
\hline 100 to 500 & 0.020 & 0.023 & 0.031 & 0.045 & 0.005 & 0.035 \\
\hline $500+$ & 0.017 & 0.017 & 0.029 & 0.033 & 0.000 & 0.010 \\
\hline
\end{tabular}

1 Countries are weighted by aggregate employment

* French data do not fully reflect the importance of small manufacturing firms as there is a floor on the sales revenue 
Table 3 - Trade Shares

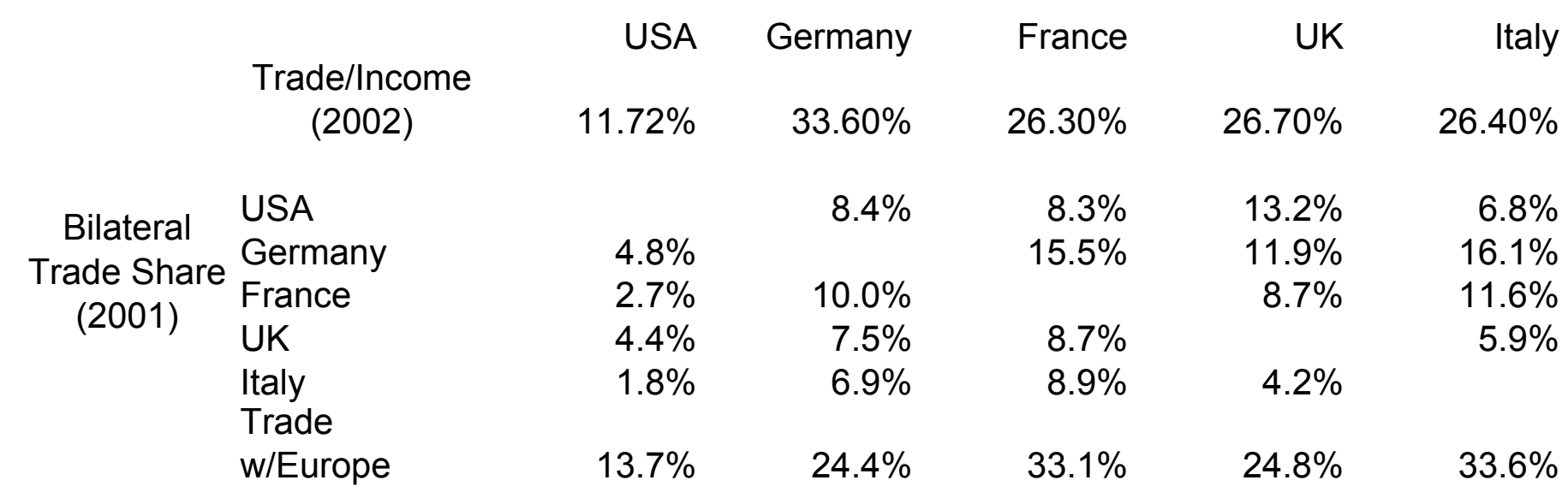

This says that $4.8 \%$ of US trade is between the US and Germany. 


\section{Table 4 - Results (base case $y=1$ )}

(Reported results are relative to the rigid case)

\begin{tabular}{|c|c|c|}
\hline & $\begin{array}{c}\text { Rigid } \\
\text { economy }\end{array}$ & $\begin{array}{c}\text { Flexible } \\
\text { economy }\end{array}$ \\
\hline Average firm size & 100 & $+5.47 \%$ \\
\hline Average productivity & 100 & $-1.07 \%$ \\
\hline JCR & $9.4 \%$ & $12.1 \%$ \\
\hline Output & 100 & $+3.43 \%$ \\
\hline Hours & 100 & $+4.50 \%$ \\
\hline Real wage (w/p) & 100 & $+4.13 \%$ \\
\hline Redistributions $\left(^{*}\right)$ & 100 & $-11.82 \%$ \\
\hline Entrants & 100 & $-0.97 \%$ \\
\hline
\end{tabular}

$\left.{ }^{*}\right)$ Profits plus adjustment costs.

Terms of trade, consumption and welfare:

Terms of trade

Trade share $=20 \%$

Consumption

Welfare gains (\%)

Trade share $=5 \%$

Consumption

Welfare gains (\%)

Non-transfers (TS=20\%)

Consumption

Welfare gains (\%)

\section{$\underline{\mathrm{RR}}$}

$0 \%$

100

$0 \%$

100

$0 \%$

100

$0 \%$
$\mathrm{FR}$, in $\mathrm{F}$

$-4.13 \%$

$+3.17 \%$

$-0.09 \%$

$+3.89 \%$

$+0.64 \%$

$+3.14 \%$

$+2.46 \%$
FR, in $\mathrm{R}$

$+4.13 \%$

$+0.97 \%$

$+0.97 \%$

$+0.24 \%$

$+1.00 \%$

$+1.00 \%$
$+4.13 \%$

$+0.88 \%$

$+4.13 \%$

$+0.88 \%$

$\frac{\mathrm{FF}}{0 \%}$

$+4.14 \%$

$+3.46 \%$ 
Figure 1. Trade Shares over time

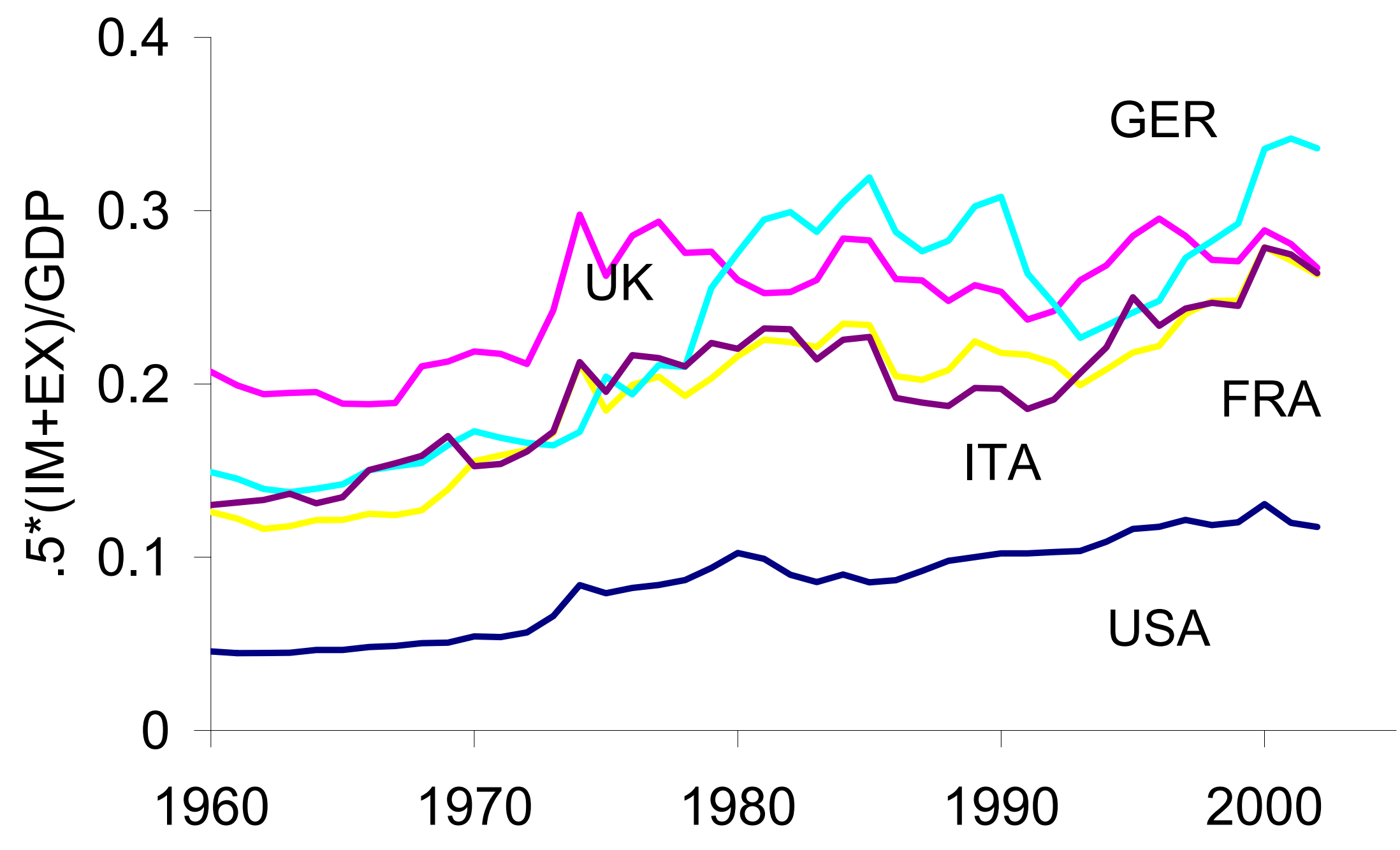


Figure 2. Welfare gains from removal of firing costs

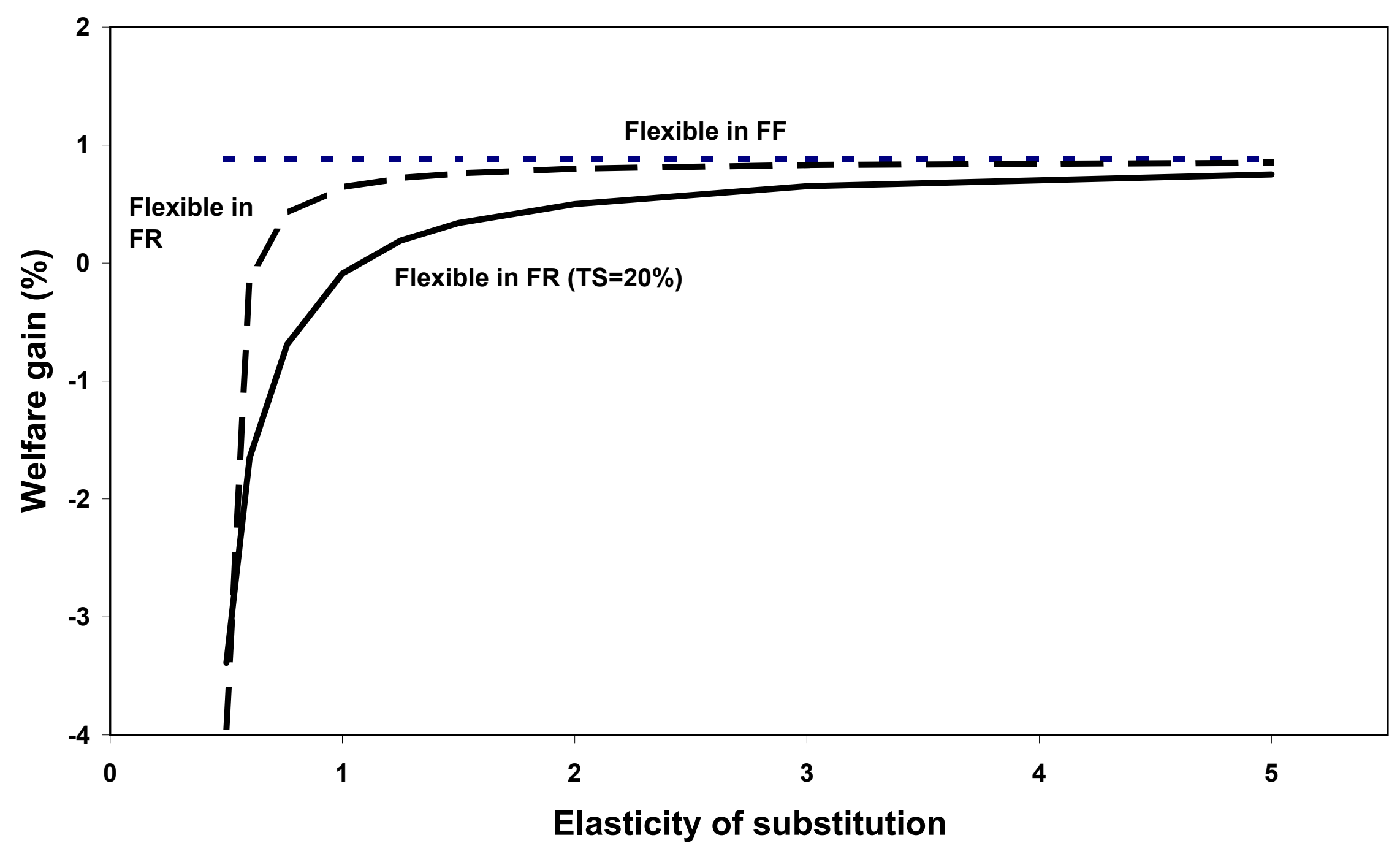


Figure 3. Terms of trade

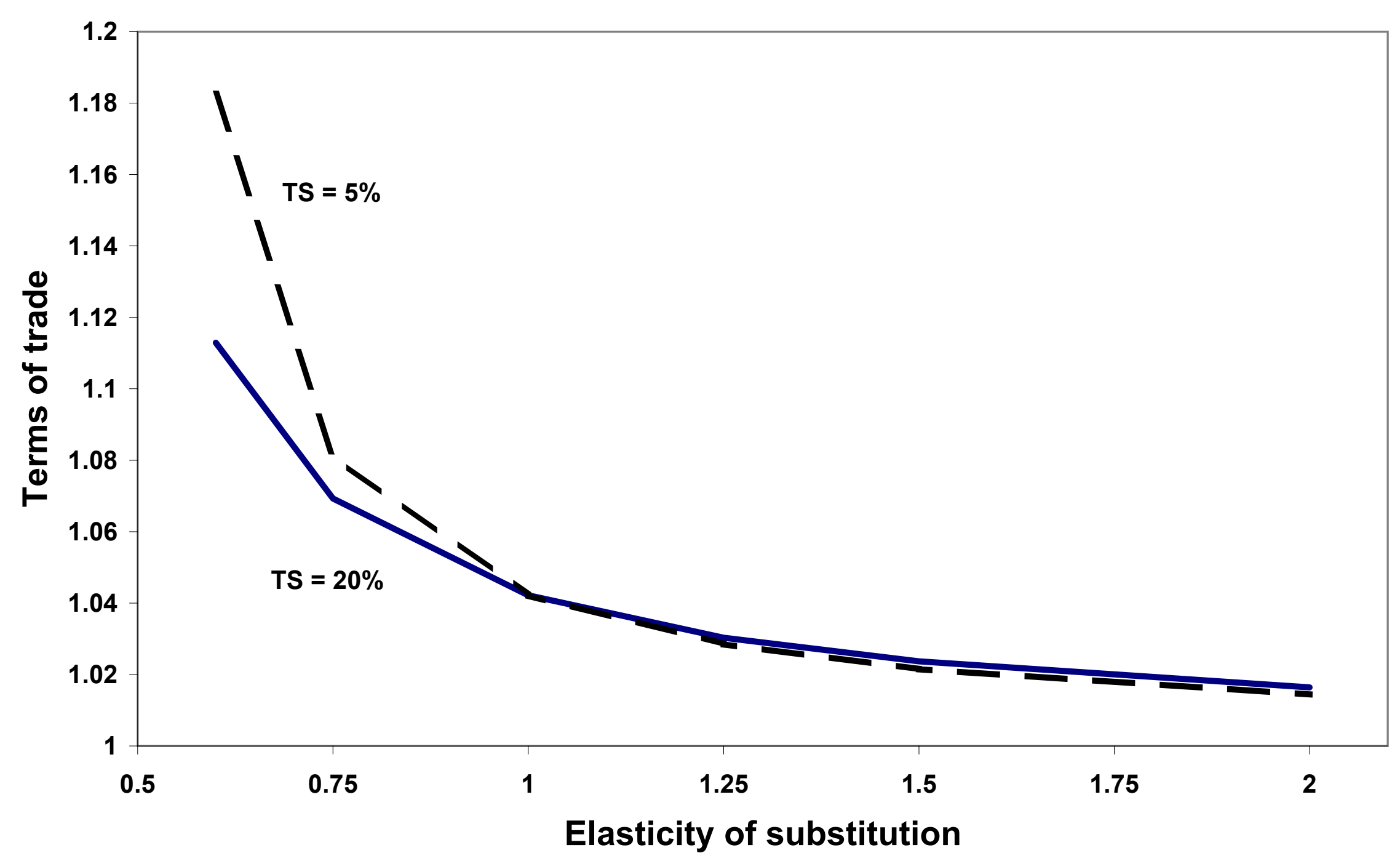


Figure 4. Welfare Division - Comparative Advantage

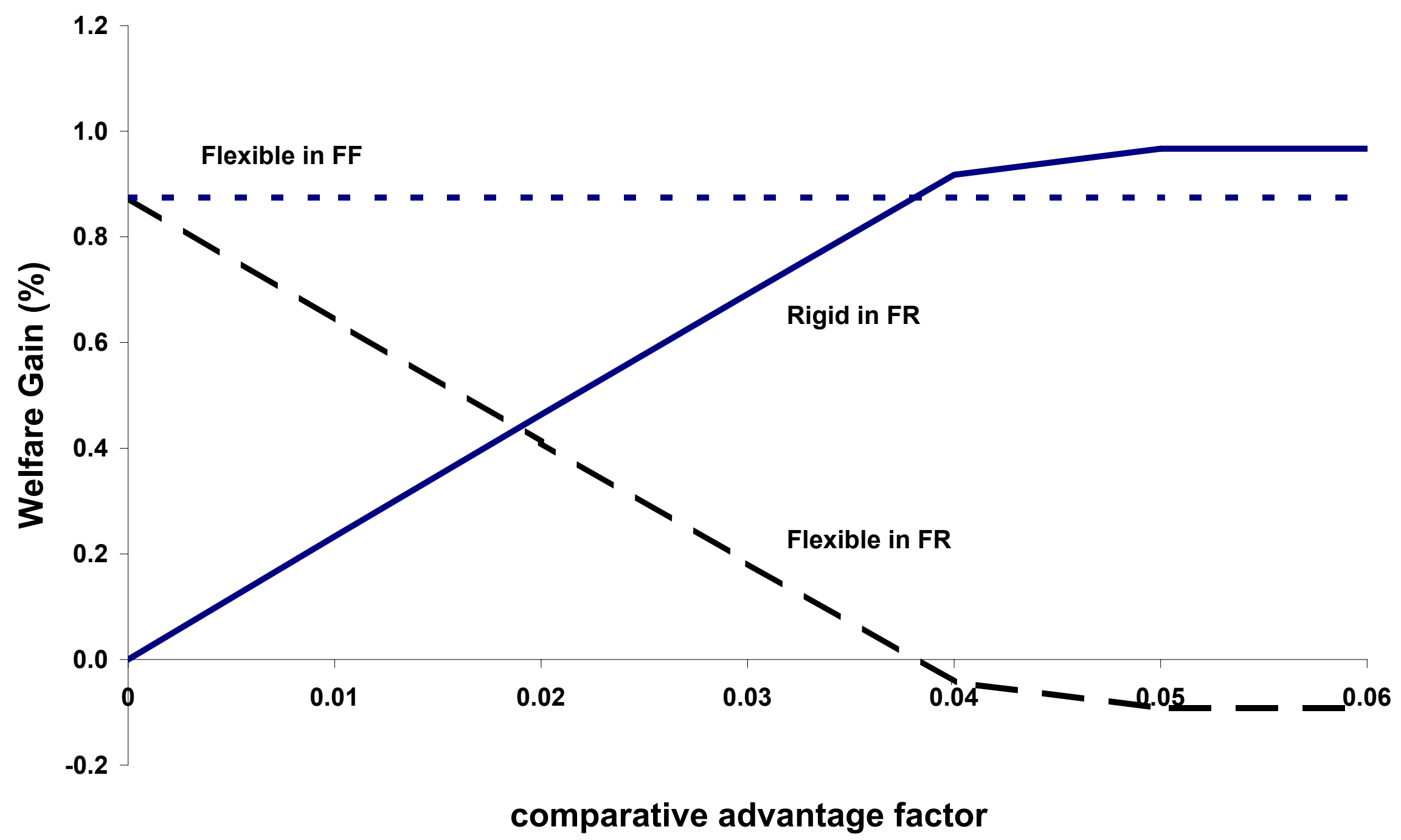


Figure 5. Best response functions

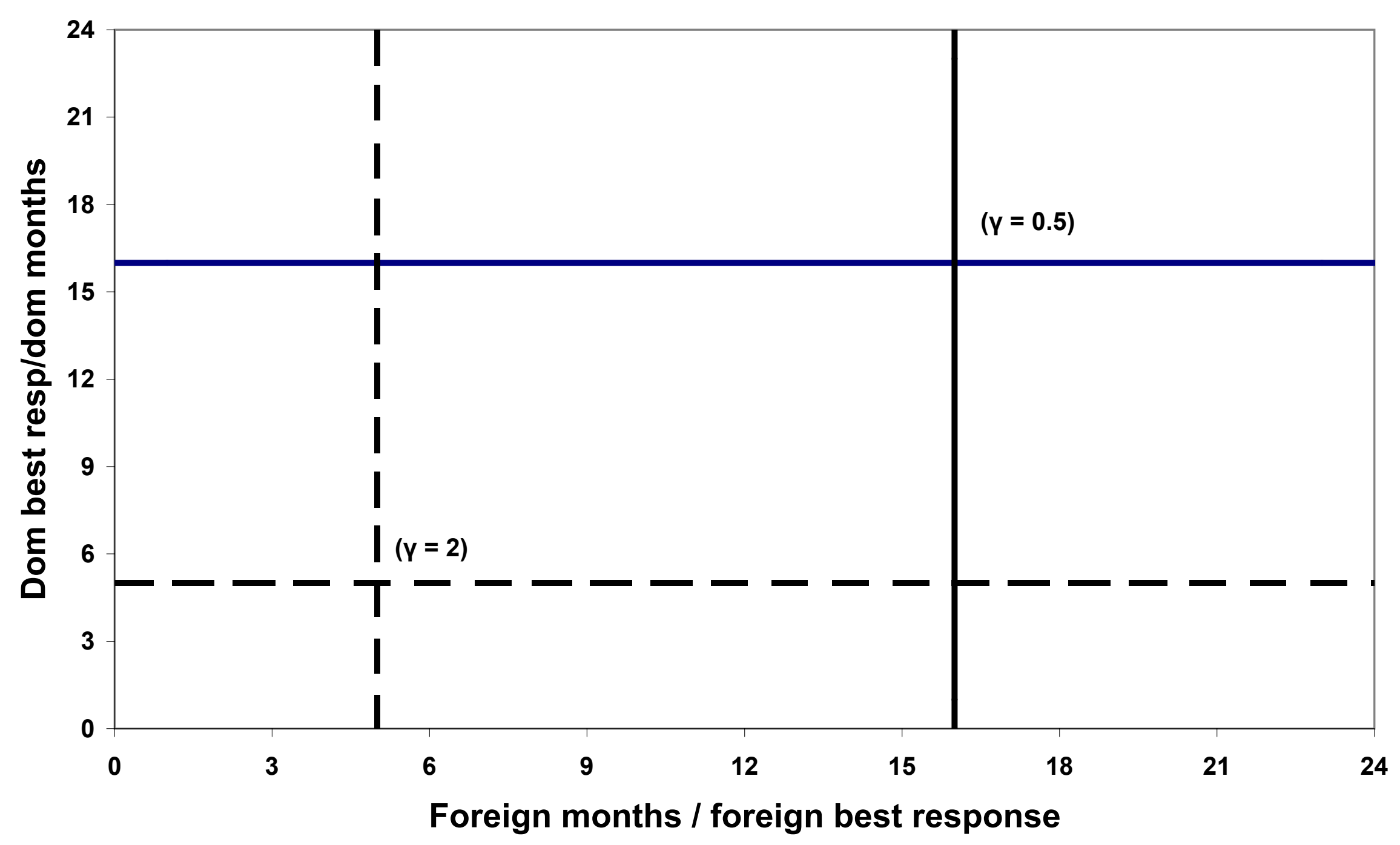


Figure 6. Changes in hours and output

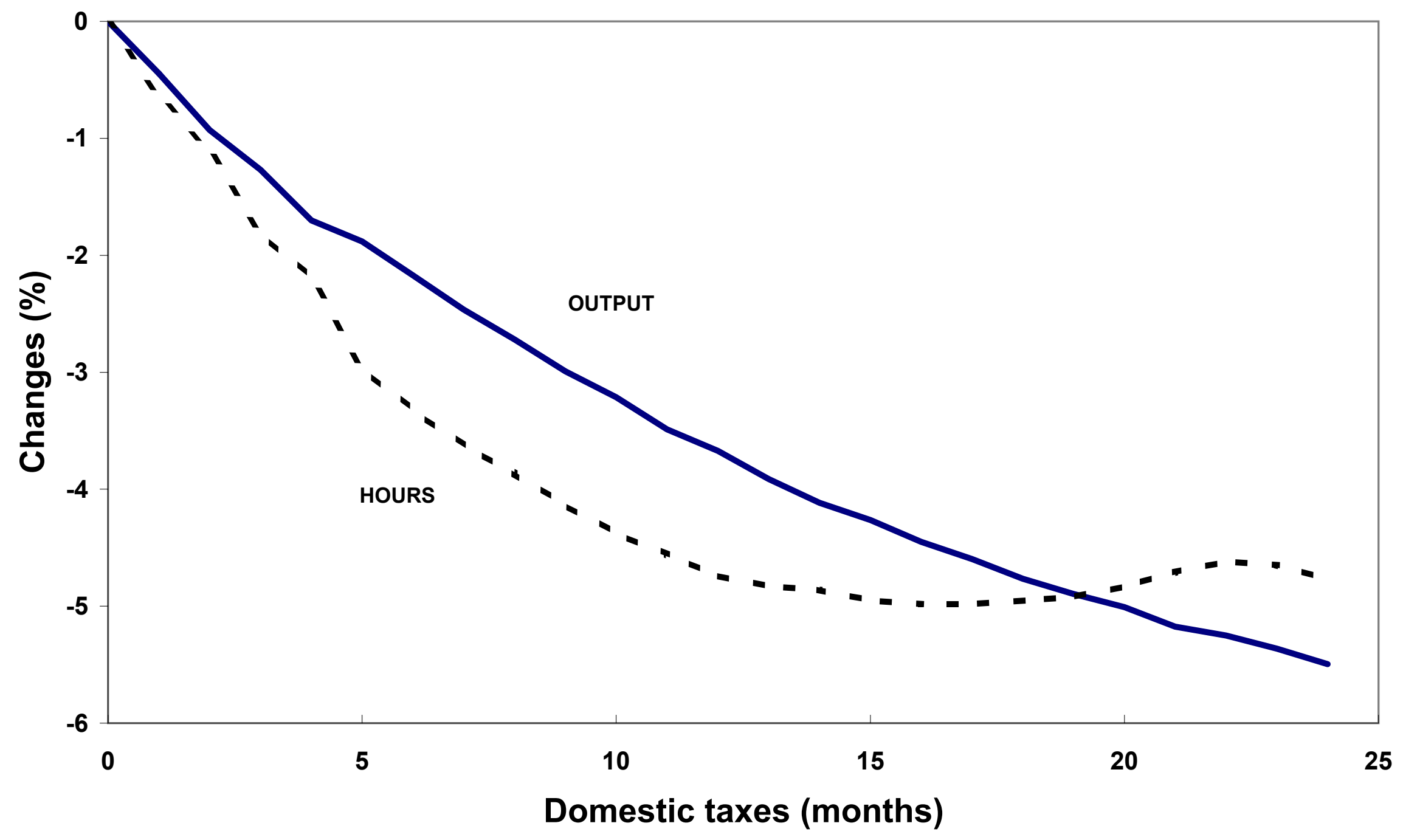


Figure 7. Equilibrium number of months of firing taxes

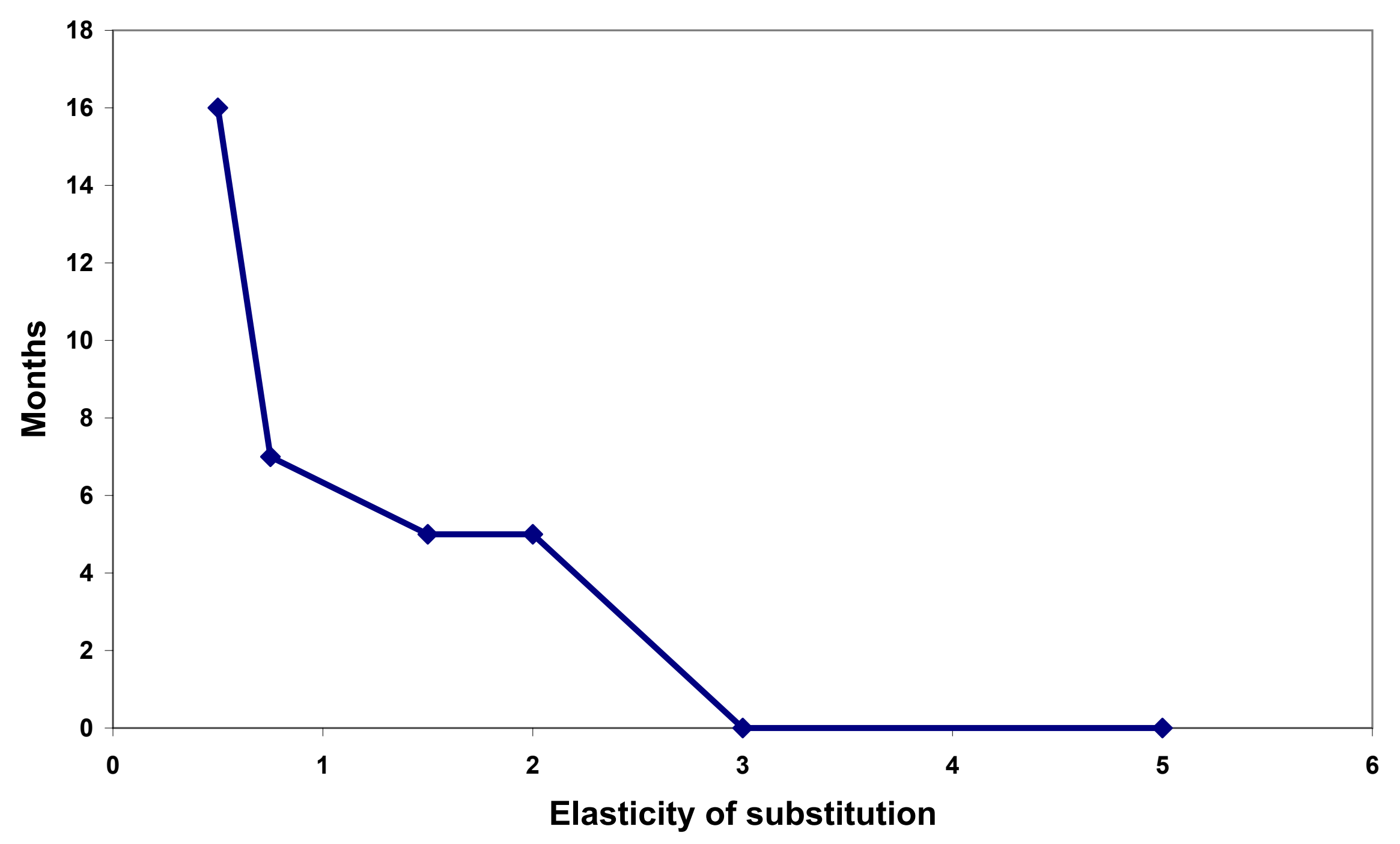

